Complutense Journal of English Studies

ISSN: 2386-3935

\title{
Revisiting Female Resilience within the Psychiatric in Janice Galloway’s Fiction
}

Irene González Sampedro ${ }^{1}$

\begin{abstract}
The aim of this article is to analyse the fractures in the performance of normative discourses of identity in Janice Galloway's novel The Trick Is To Keep Breathing (1989) and her short story "and drugs and rock and roll", included in her latest collection Jellyfish (2015). Drawing on the thematic dialogue between the two works, set in Scotland, this article focuses specifically on their protagonists' processes of healing following a period of depression, and the urban spatial representation of these experiences. In order to do so, it examines various practices associated with psychiatrics that isolate and dehumanise citizens and lead to the creation of a sharp social dichotomy as regards wellbeing. Finally, the article approaches the spatial embodiment of these characters, as well as the creation of alternative spaces inside medical institutions as part of a continuum in Galloway's exploration of female resilience.

Keywords. Janice Galloway; urban studies; psychiatry; female resilience.
\end{abstract}

\section{[es] Revisión de la resiliencia femenina dentro del psiquiátrico en la obra de ficción de Janice Galloway}

Resumen. El objetivo de este artículo es analizar las fisuras que surgen en la repetición de discursos sociales normativos en la novela The Trick Is to Keep Breathing (1989) y en el relato "and drugs and rock and roll", de Janice Galloway, que aparece incluido en su última colección Jellyfish (2015). A partir del diálogo temático entre ambas obras, contextualizadas en Escocia, este artículo se centra específicamente en el proceso de curación de las protagonistas tras una depresión y en la representación espacial urbana de estas experiencias. Para ello, se examinan diferentes prácticas asociadas a los psiquiátricos, que contribuyen a aislar y deshumanizar a sus pacientes, al tiempo que crean una dicotomía social basada en el bienestar. Finalmente, el artículo aborda las experiencias corporales de estos personajes, así como la creación de espacios alternativos dentro de las instituciones médicas como parte de un continuum en la exploración de la resiliencia femenina efectuada por Galloway.

Palabras clave. Janice Galloway; estudios urbanos; psiquiátrico; resiliencia femenina.

Contents. 1. Introduction. 2. Dehumanisation within Urban Public Spaces: The Psychiatric. 3. Female Resilience Practices in Mental Institutions. 4. Conclusions.

How to cite this article: González Sampedro, I. (2021) Revisiting Female Resilience within the Psychiatric in Janice Galloway's Fiction, in Complutense Journal of English Studies 29, 35-44.

\section{Introduction}

Glasgow fiction shows certain distinguishing characteristics in comparison with other more fixed representations of Scotland, which are often identified with a taste for the rural and sometimes with stereotyped ideas of the Highlands. Among these distinctive features is the use of the local dialect, known as Glasgow Patter and mainly employed by the working classes, in conjunction with a wide range of themes oriented to how people endure the difficulties of the economic and social crises to which the city has been exposed. This urban literature has also been interpreted as a response to the frustration stemming from the political atmosphere of the $20^{\text {th }}$ and $21^{\text {st }}$ centuries. In the $1980 \mathrm{~s}$ and $1990 \mathrm{~s}$ in particular, writers were engaged in the redefinition of collective identity, with women and racialised writers contributing to the examination of contemporary Scottish subjectivities. During this period, acclaimed writers such as James Kelman, Alasdair Gray, A. L. Kennedy and Jackie Kay, among others, problematised Scottishness from new angles (Schoene 2007). In this vein, Ian Bell situates Glasgow at the epicentre of a literary tradition in which authors explore individual identities circumscribed by "alienation and fragmentation, moments dramatising the loss and discovery of self" (1996: 226). Carol Anderson also adds a gender perspective and explains, "if

Universidad de Oviedo

ORCID: 0000-0002-0765-1952

E-mail: iregsam@gmail.com

Complut. j. Engl. stud. 29 2021: 35-44 
male Scottish authors (...) had to contend with difficulties generated in part by a problematic relationship to national identity, language and literary tradition, for Scottish women this experience [was] compounded by gender" (1993: 171).

Janice Galloway started her literary career in the aforementioned period of the 1980s and 1990s with the publication of her acclaimed debut novel The Trick Is to Keep Breathing (1989), in which she explored the renegotiation of Scottish female urban experiences, regulated by patriarchal ideology, by means of a character, Joy Stone, and her attempt at overcoming an emotional turmoil. Throughout its pages, Galloway employs innovative stylistic devices to represent the fragmented identity and dissociated mind of her protagonist, which she uses to deconstruct patriarchal language through lexical items and linguistic structures (Hock Soon $\mathrm{Ng}$ 2012: 238). Writing in the margins, blank pages, suspended sentences, rambling words and typographic symbols shape a novel that can also be seen as an allegorical character in itself and which has had a great influence on other contemporary works, such as in Denise Mina's Garnethill Trilogy (1998, 2000, 2001), Louise Welsh's The Girl on the Stairs (2012), and Zoë Strachan's Negative Space (2002). Three decades later, her work still interrogates and redefines hyper-masculinised forms of Glaswegian identities from a feminist perspective that allows her to write, as Moira Burgess contends, not "about, but through, Glasgow. Her gripping short stories often have, and need, no specific setting, focusing as they do on one moment of epiphany, of emotion, crisis or choice. Where there is a streetscape, it may well reflect not Glasgow but the bleak semi-urban hinterland where she grew up" (1998: 311). Galloway analyses the complexities of female identities in the city and provides a new gender perspective through which to make visible their experience of oppressive urban practices, as well as the strategies women have developed to overcome them. This is often done by means of audacious techniques, such as, in the words of Michael Meyer: "[recording] the disturbing inner processes of her female protagonists in fragments that transcend the boundaries of realism, verging on the grotesque and the surreal" (2008: 349). In addition, her works usually centre on female characters struggling with psychological issues. Their healing processes, however, grant them the necessary empowerment to re-enter the highly conservative patriarchal society in which they live, and from which their problems stem. This is particularly the case in "and drugs and rock and roll", published in the collection Jellyfish (2015). In this short story, Alma, its protagonist and a long-term psychiatric patient, is trying to recover from post-abortion depression. Following her decision to be admitted in this institution, she will face the rejection of her partner, but also that of society as a whole, due to her condition and her unconventional determination not to fulfil her female role as a mother. Although it was published in 2015, this is not the first time that Janice Galloway has used a medical institution as an important setting for the development of her female characters. Indeed, she explored it in The Trick Is to Keep Breathing (1989) and since then she has been interested in mental institutions and the intertwining of different discourses within their grounds, for instance, in the short story "A Proper Respect", published in Where You Find It (1997), as well as in her memoirs This Is Not About Me (2008) and All Made Up (2011).

This article approaches the spatial embodiment of Joy and Alma and the creation of alternative spaces inside medical institutions as part of a continuum in Galloway's exploration of female resilience. Drawing from space and gender theory, I examine Galloway's portrayal of psychiatric hospitals as institutions that isolate and dehumanise citizens through restrictive mechanisms of control over corporality and affectivity. I also focus on the representation of female resilient practices and their ability to transform mental institutions by blurring the boundaries between public and private spaces and creating different living conditions.

\section{Dehumanisation within Urban Public Spaces: The Psychiatric Hospital}

The psychiatric hospital is an urban space conceived to fulfil two objectives: the overcoming of mental illnesses and the subsequent reintegration of patients back into their communities. However, these medical institutions also play a determining role in the deliberate isolation of certain subjects who do not fit into established health parameters. In Health and Inequality, Sarah Curtis argues that psychiatric hospitals have traditionally been built in areas located outside urban centres, so that society can perpetuate an idealised image of general wellbeing (2016). This work, like many others, is influenced by Michel Foucault's seminal study of the construction of psychiatric hospitals as spaces of discipline, where he analyses the mechanisms they employ to perpetuate social inequalities, which are sustained by a discourse that classifies individuals according to their capacity to adjust to the type of normativity it produces. Regarding this, he points at "the displacing of medical intervention and the application of discipline to the space of the hospital" (2007a: 148). Similarly, Curtis argues that it is controversial that patients must undergo a partial loss of agency in hospital care, due to the control exercised by doctors and their strict schedules. Nonetheless, it is possible to find people "resisting medical authority and control over their bodies and their action in time and space" (2004: 57). This idea of resistance is closely related to a term that has gained momentum over recent years, resilience. Patrice M. Buzzanell (2010) defines it as the capacity to recover from a hard experience, of "crafting normalcy", reaffirming one's identity, participating in a communicative process, offering alternatives and avoiding negativity. Although this capacity has been celebrated by neoliberal agendas, it has also been criticised, since it often implies that disadvantaged people 
must endure individually difficult situations that could be prevented if only supportive social structures existed (Evans and Reid 2014). The resilience processes analysed in this article go hand in hand with the evolution that the discipline of psychology has undergone in the last decades by introducing a feminist perspective. It is worth mentioning, for instance, Judith Worell's study on the social oppression exerted on women and how feminist psychology has helped by "(1) opening innovative areas of research by asking new questions; (2) naming and renaming the problems; (3) challenging research methods and priorities; (4) revising approaches to therapeutic practice; (5) integrating multiple diversities; (6) applying research to public advocacy and legislative policies; and (7) transforming programs and institutions to render them more collaborative and woman friendly" (2000: 188).

A similar critical perspective on resilience and discriminatory mechanisms permeates Galloway's fiction, especially The Trick Is to Keep Breathing and "and drugs and roll and roll". Both texts deal with female embodiment within psychiatric hospitals. In her novel, the author redefines the hospital from being a public space into being a home in which Joy creates a fellowship network with the rest of the patients, despite their isolation from society. Galloway uses the name of the psychiatric to emphasise their physical and social dislocation. In this sense, Foresthouse Hospital - inspired by the Glaswegian Forrest House Care Home, a nursing home for elderly and disabled people - evokes a rural character and a disruption of the medical and technological innovations typical of urban culture because of its reference to the forest. Additionally, Joy places the clinic in an isolated area of the city: "[f]our roads converge from the surrounding fields to the carpark. The carpark is at the foot of the hills. Foresthouse Hospital sits at the top of the hills, a shoebox slatted through with glass" (Galloway 1989: 110). The elevated location of the hospital also emphasises the importance that medical institutions have in the population, and their impact on the geopolitical discourse (Foucault 2007a), which combines knowledge and power, decentralising, physically and metaphorically, people who are not considered suitable to live among "regular" citizens. In this way, those living at Foresthouse Hospital are relegated to a low social level, since they do not have the ideal characteristics that the population should possess, such as being young, healthy and without any type of disability that prevents them from carrying out a job to contribute to an economy that perpetuates inequality.

Later in her production, in "and drugs and rock and roll", Galloway will revisit this spatial transformation based on the affective needs of the main characters. Although in the story the whereabouts of some of the institutions are not explicitly mentioned, again the author alludes indirectly to a real and well-known hospital, The Priory, which is juxtaposed with the hospital where the protagonist has been admitted. This mental institution is located in a residential area on the south bank of the Clyde, following the common decision of situating these buildings on the outskirts in order to separate 'unhealthy' social subjects from lively and modern city centres. In contemporary global cities, where difference - particularly economic and body difference-is considered a menace to the branding of a city, these marginal subjectivities become part of what Saskia Sassen defines as the amalgamated Others (2000), whose experiences are invisible due to the segregation of urban space. In the analysed text, The Priory appears to be a differentiating marker of social class among patients, as it is a private and exclusive clinic, inducing those in the South Cross General Hospital to assume their secondary social status, which derives from their mental disorders and their poverty. In fact, Rhonda, one of the female inpatients at the latter hospital, underlines the idea of social isolation by describing quite graphically the place they are living in: "[a] holding pen - correction - an understaffed holding pen with sedatives that must drive the folk who work here crazy as well. It's not exactly The Priory, isn't it?" (Galloway 2015: 44-45). The word pen carries negative connotations, as a cage, a penitentiary or, taking into account that she considers her definition as a holding pen, it can even be pictured that she feels herself like a caged animal, which confirms their feeling of social incarceration.

Foucault claims that imaginary geopolitics is represented by the symbolic organisation of space and, more specifically, through architectural organisation. For him, there is a network of power relations embedded in the supervision of the state apparatus, and as such hospital space is configured according to the English philosopher Jeremy Bentham's model of a prison (1995), the Panopticon, which was later conceived by Foucault as "an ensemble of mechanisms brought into play in all clusters of procedures used by power" (2007b: 178). The inside of the psychiatric hospital in The Trick Is to Keep Breathing is designed following this control system. In an attempt to articulate her identity within the individual space allowed to each patient, which is intended to homogenise them, the protagonist describes her surroundings as follows:

The ward is a rectangular space with beds at equal distances. The beds are grey metal frames with matching equidistant lockers. The lockers have an upper box which is open and a lower with a door. They don't lock. There are names sellotaped to the lockers with clear tape. (...) My bed is one from the door open end of the ward and two from the window end. The window has crimson curtains: the entrance to the ward is open. The floor tiles are white, green and blue. Behind my locker there is a toilet and shower block. The covers on the beds are crimson and the sheets white. There are two pillows for each bed, eight beds in the ward. The beds are single and cranked very high. There is no-one but me. (Galloway 1989: 114-115) 
Framed by this rigid macro-space, the protagonist defines herself as an insignificant subject who has to rethink the living space she occupies in order to give meaning to her existence. Joy has to decide whether to view the psychiatric hospital as a new home, through her acceptance of its values, or whether to feel imprisoned and detached from the rest of society, which would further worsen her physical and mental health. Yet trying to cope with her alienation implies escaping from the strategies that reproduce this conservative system. Despite writing her activities in a diary, as requested by the doctors in order to determine her readiness for reintegration into society, Joy only reflects on her true intentions to see her difference as positive in the letters she sends to a friend, thereby avoiding the scrutiny of the psychiatrists. In this way, she becomes an active agent in her own life by subverting the rules and finding an alternative way of living.

"and drugs and rock and roll" also represents a fixed hierarchical structure within a medical institution, and specifically within the ward where the patients live. In order to maintain control over them, the hospital has established routines which must be followed by all of its members: "[t]he round-up would start soon, names, notes, night allocation, bed: the trolleys were banging around already" (Galloway 2015: 40). This logistics creates norms of conduct that classify the patients' behaviour and experiences. This also provides doctors and the rest of the medical staff with a position of authority over those who cannot make decisions for themselves, in a place where "illness in general was nobody's business. Asking too much was not done. It was poking one's nose" (Galloway 2015: 38-39). To this end, the series of routines works as an overprotective mechanism that contributes to the invisibility of the patients' needs, which are not attended to properly. Indeed, Rhonda's complaint mentioned above focuses on the depersonalisation of the patients, which fundamentally stems from the doctors and nurses' lack of involvement in their problems. This distant attitude is reflected in the cold and sometimes unpleasant treatment that the hospital staff give patients. For instance, Victor, the only male nurse, searches Roxanne's room, invading both her privacy and the privacy of her roommates: "[h]e opened Roxanne's locker drawers, forking his fingers through her letters, her unwashed tights", and exclaiming "[p]ardon my French, but she's fucking obscene" (Galloway 2015: 37). He uses this derogatory comment to downplay his lascivious behaviour when he touches her underwear, the negative construction of Roxanne's sexuality being employed to disassociate himself from his real intentions and censurable behaviour.

The ambiguous character of Victor is particularly interesting to analyse the spatial subversion of gender roles. In spite of his reprehensible behaviour, readers can identify his struggles to fit into a historically feminised profession. Even the patients spread stories about his poor performance as a nurse:

Somebody said Victor left some old guy in a puddle of shit for an hour before he could be bothered shifting him. At least, so he says. Lazy pig.

We all have bad days, Alma said.

He's not supposed to have bad days, Dianne snorted. He's supposed to look after people. That's the whole idea behind nursing, you know? Care. (Galloway 2015: 38; emphasis in the original)

Here patients are projecting their expectations about characteristics traditionally attributed to women and, by analogy, to nursing: patience, care, love and blind devotion, among them. Victor does not fit here because his masculinity is questioned: he works as a nurse and, at the same time, he is expected to perform a heteronormative identity. Consequently, he goes through a process of resilience in order to find subversive ways to show his manhood. He does so by wearing scruffy clothes, even though uniforms are compulsory at the hospital: "[n]ow in those low-slung jeans he liked and zooming in like a heat-seeking missile on Roxanne's bed, he was ready to give us a go at the same. (...) The elastic band of his man pants said GUESS" (Galloway 2015: 36). This elastic band has a double function. On the one hand, Galloway wants her readers to experience the story in detail, as her characters would do, and for that reason she gets the readers' attention through the use of this marketing device. In this vein, Sacido Romero explains that "for Galloway, corporality, physicality, sensuality, in sum, the body is to be rescued from extinction through writing and shared with the reader in what constitutes a truly universal experience" (2019: 134, emphasis in the original). Thus, the readers become part of the story and not only mere spectators, since they are allowed to look through the main character's eyes. On the other hand, this word, written in capital letters, works as a veiled and sexualised message. In this sense, the waistband of Victor's underwear invites the female gaze - given he is in the women's ward of the hospital - to be curious about his virility, which reinforces his hypersexualised masculine identity. He claims his coldness is a consequence of the cuts derived from the economic crisis that has struck the country and which has had devastating effects on people's lives and on the public administration. These economic problems can be seen when he complains: "[h]ere's less wages and less funding — same story every year. Ye canny win. It'll be private this time next year, you wait and see. You might be the last of a dying breed, Alma" (Galloway 2015: 54). Regarding the production and reproduction of discourses, Sara Ahmed and Jackie Stacy (2001) argue that our skin acts as a material and symbolic boundary between bodies and the spaces they occupy, favouring the circulation of emotions. Here, Alma and her mates feel how they are conceived as a burden on the State because there is a lack of funding - or a lack of interest in using economic resources for those purposes - and Victor reproduces those messages through his mood and dehumanised way of treating the inpatients. 
In both works there exists a dehumanisation process when the characters deal with the medical staff. In The Trick Is to Keep Breathing, for instance, Joy constantly distances herself from them by labelling herself "IMPATIENT" in the transcript of their conversations. Mary McGlynn explains that "the reader sees playscript when Joy feels powerless or when she believes the outcome of a scene is predetermined" (2008: 233), and, in this sense, it can be observed that the protagonist is afraid to show her weaknesses and concerns. For example, her visits to the doctor appear structured and timed:

$\begin{array}{ll}\text { IMPATIENT } & \text { OK, let's talk straight. You ask me to talk then } \\ \text { you look at your watch. What I am supposed to } \\ \text { take from that? This whole thing is ridiculous. } \\ \text { Can't you send me to someone who's paid to } \\ \text { have me waste their time? You don't know what } \\ \text { to do with me but you keep telling me to come } \\ \text { back. And stop sending that woman to see me. } \\ \text { All it does is make me guilty and secretive. } \\ \text { Look, this is reactive depression. I don't see that } \\ \text { sending you to a specialist will help things. Talk } \\ \text { to your family if you can't talk to me. } \\ \text { I have no family. } \\ \text { IMPATIENT } & \text { Don't be melodramatic. (Galloway 1989: 52-53) } \\ \text { DOCTOR } & \end{array}$

By distancing herself from the conversational context due to the passivity that the doctor shows, Joy imagines a dialogue with him in which she becomes an impatient character who verbalises the concerns she has. In this way, readers perceive her annoyance at having to express her feelings in front of doctors. In addition, her reluctance is evidenced by the way she lies about her personal life in order to meet social expectations. It can be seen, on the other hand, that what exasperates her the most is the way in which medicine tries to minimise personal problems, especially women's issues, as doctors refute their arguments by considering them melodramatic. On the other hand, this quote highlights, as Carla Rodríguez González points out, Joy's loss of "identity, once her problem passes into the hands of the doctors" (2006: 144), as well as, in Joy's opinion, the futility of this type of formal relationship (Jones 2009: 74).

In contrast, the consultation with the medical staff is repetitive and highlights the lack of communication between professionals in the sector: "Dr Four says I need ECT, Dr Two thinks I need a good holiday and a career move, Dr Three thinks I take too much caffeine - a bit less and I'd be fine. Also a Dr Five turned up and suggested maybe we could have a chat" (Galloway 1989: 179). To begin with, the doctors who treat her in the psychiatric hospital do not have names, but are differentiated by numbers, meaning that "the effect achieved by the use of numbers is one of detachment and homogeneity, so that the reader is forced to feel antipathy towards [the doctors]" (Delgado Delgado 2000: 318). In addition to this feeling, their numbering responds to the impersonal treatment that the protagonist receives in the consultation. Despite being sincere with Doctor One, he has not taken note of Joy's story, so the male nurse, who she thought was Doctor Two, repeats the same questions, causing the protagonist to reveal to us in the margin of the page: "sometimes that feeling deja vu" (Galloway 1989: 110), emphasising the absurdity of the repetition of details:

Someone else comes and settles into Dr. One's chair. He says

So. Why do you think you've been sent to us?

I say Sorry? And he says

So. Why do you think you've been sent to us?

I blink once and say, Dr One told me to come in. I'm here by invitation.

Yes, but why do you think you were referred? What's the problem as such?

(...) Look, I did all this. I told all this to Dr One just three days ago. I did all this for Dr One. Maybe there are some notes. (...)

That may be so but this is different. This is for records. For records. (Galloway 1989: 110-111; emphasis and empty line in the original)

The lack of willingness to consider her feelings and trauma in relation to the dramatic experiences she has had is shown when the nurse refers to her problem with the words "as such". In the same way, the health workers record superficial details when they create a report of the events that have led to Joy entering the hospital, and hence they do not state the protagonist's real problems: anorexia and alcoholism, which are aggravated by her rejection of predetermined gendered social behaviour. In this sense, Mary McGlynn claims that "[doctors] repeatedly miss opportunities to intervene or even comment on her anorexia. Their callous refusal to notice her unhealthily thin body resembles the ignoring that inspires the anorexic to continue her starvation until she 
is noticed" (2008: 226). Specifically, their inability to relate physical and psychological symptoms leads them to make a mistake in their diagnosis to the extent that, for example, given the protagonist's amenorrhea, they think that she is pregnant, instead of relating it to her extreme thinness and considering it an indicator of her eating disorder.

Galloway continues to explore this dehumanisation within the hospital in "and drugs and rock and roll", where it strongly impacts their patients' agency, especially in the case of Alma and her female friends. For instance, it is evident in the indifference that one of the nurses shows towards patients: she does not even know their names despite being in charge of their medication. However, this is a two-fold process where Alma too manifests her prejudices, as she refers to her as the "night-nurse" because she seems to be new and she has not had time to know her well. In addition, she does not give doctors proper names, which creates the effect of detachment and impersonality. In this manner, when referring to the Doctor, the word is written in capital letters so that he is identified as the true and rightful font and bearer of knowledge. Moreover, this juxtaposition of authority and the forced ignorance of the patients can be observed in the emptiness of the library: "[t]he library that had no books or seats in it and the nursing bay showed open doors but no one inside" (Galloway 2015: 42). The fact that the library has neither books nor chairs is an indicator of the institution's lack of interest in having independent subjects under their administration.

On the other hand, Victor is well-aware of the significance of his name. Given that it means the conqueror, he interiorises his symbolic superiority in order to exercise control over the patients. Adopting a paternalistic position, he criticises Alma when he discovers that she is reading a book: "[y]ou reading again? They make you go daft, books" (Galloway 2015: 52). Here, Victor sees himself as the only person who should be granted access to knowledge, which situates him in an advantageous position with respect to the protagonist, who is also made to feel inferior due to her need for medical assistance, as well as for being a woman. In addition, he makes use of a hypocritical discourse when he criticises other men, like Scottish writer Trocchi, for using women as a means to achieve their goals. Although he penalises their behaviour, he makes it clear that rules are established by men, and women must perform passive roles: “[o]y, Victor said. Language. There's vulnerable women here. (...) That's a terrible attitude you've got there, young lady. And a very dirty mind" (Galloway 2015: 53-54). The construction of the protagonist's identity is thus based on an image of obedience and appropriate behaviour. The submissive and passive role assigned to women is reinforced by calling her "young lady" and by sedating her after the exchange in order to prevent her from causing problems: "[g]ood girl, he said, crushing the cup in one hand, putting it into the bedside bin. When was the last time you heard that, eh? Good girl' (Galloway 2015: 54; emphasis in the original).

In the context of psychiatry, medicalisation disengages patients from their own free will and contributes to their alienation and the creation of passive subjectivities, perpetuating a hierarchical system within healthcare institutions:

[The nurse] handed over a paper cup. Not diothepin, not protriptyline, not lorazepam or tranylcypromine either. Alma couldn't remember what the new stuff they had put her on was called but it made her less hazy. That meant it was working, she supposed. (...) The reliable thing was medication. Alma's had been changed so many times she had lost track. Lying shivering under the hospital issue blanket — bed was always cold till you surrendered to being there-Alma tried to work out if she had done anything today. Anything at all. (Galloway 2015: 49)

Alexandra Howson (2013) sees the extended use of medicalisation as the consequence of a discourse that situates medicine as the remedy for any social problem. In Galloway's story, the psychiatric hospital contributes to regulating the conduct of women and invisibilising their divergent experiences through sedatives. Additionally, the protagonist's abstraction is also represented by her name. Alma means soul in Latin, thus the name focuses on only one element of the body/soul dichotomy. Alma, along with the other patients, appears as an incomplete human being, a wandering soul in a space of confinement. In spite of this division, she embodies the Purgatory at the hospital, a space of loneliness and the constant search for her identity after her abortion.

Foucault focuses on the internal configuration of hospitals as both an individual and a collective way of control that guarantees "the inquiry, surveillance, and application of disciplines into the disorganised world of the patients and of illness and (...) transform[s] the conditions of the environment which surrounds the patients" (2007a: 148). In "and drugs and rock and roll", the narrator describes the disposition of a communal lounge called the Quiet Room in a detailed way:

The Quiet Room was quiet partly because it had a piece of foolscap with SHHHHHH written on it singletacked to the wall, but more because hardly anybody went in there because it had all the charm of a box room. It was also freezing. One table, three chairs, a broken heater — nothing else. Staff sometimes put flowers there to keep them fresh. (Galloway 2015: 43) 
The coldness hinted at here is perceived not simply on a physical level. The broken heating system stands for the general lack of interest of the medical staff towards the patients' needs. Furthermore, the staff's almost absolute control over the patients is reinforced by the silence sign on the wall forbidding any expression of resistance to their authority. However, Alma is able to reconfigure this space according to her personal needs, as "a place she could jam the door [shut] with a chair and cry all day if she felt like" (Galloway 2015: 43). Given that this is the only place where she can hide, the emptiness and coldness allow her to give free rein to her sadness without being questioned or considered weak. Hence, she experiences a process of resilience because she can subvert the moral code imposed by the medical institution while also being able to create a space where she can convert the negative consequences of silence into a means of personal exploration.

\section{Female Resilience Practices in Mental Institutions}

As explained above, the psychiatric hospital is constituted as a delimiting space in which schedules and the possibilities of space act as a key element of control. However, a mental institution can also acquire new meanings when patients go through a process of resilience. In The Trick Is to Keep Breathing readers do not necessarily note an improvement in the protagonist's mental health and personal autonomy while she is an inpatient at the hospital. However, her temporary stay can be understood as a turning point in her story, because she discovers that her corporality is the best tool with which to question social norms about how women should behave. Once she returns to the shabby cottage which she previously shared with her former partner, and redecorates her home, Joy realises that she is capable of taking control over her future. In this novel, then, Galloway explores the possible consequences of having gone to a mental institution and then leaving it, but in "and drugs and rock and roll" she examines the process of female resilience within the medical institution. This is especially noticeable in her treatment of how female inpatients are able to create a domestic microcosm in spite of the socialisation problems they have. These problems relate to their attitudes towards identity markers such as mothering, embodied differently by Alma and another patient called Dianne.

Dianne has been an inpatient for many years. Although her full story is never revealed, the reason for her hospitalisation is related to the guilt she feels about her daughter Sandra, who is twenty-five and needs to use a wheelchair, because of an accident she had when she was only ten. Dianne is not able to cope with her daughter's grief and her own responsibility for the accident, despite her husband Declan's attempts to continue their lives together as a united family. Consequently, her situation is rather paradoxical: she is in good health physically, but is locked in the psychiatric hospital because she is unable to overcome her pain. As a counterpoint, her daughter is not admitted to the hospital despite her lack of mobility and her need for high levels of care. The fact that Dianne is hospitalised suggests that the less control people have over their lives, the less able they are to perpetuate the expected social roles, and therefore, the more marginalised they become.

Moreover, this discrimination for not fitting into a predetermined social role is symbolically manifested in the public means of transport that appear in the two stories. In The Trick Is to Keep Breathing, there is a lack of bus connections between Glasgow and the house where Joy used to live with Michael. In this way, her spatial disconnection resembles the social segregation she experiences due to her relationship with this married man. In contrast, in the short story "and drugs and rock and roll", Dianne's inability to perform her role as a mother is compensated for by Declan's devotion. He becomes the caring figure at home in an interchange of gender roles. He starts to cut down on his visits to Dianne because he prioritises his daughter, who cannot access public transport as she points out: "[h]e'd be here all the time only our Sandra's chair is verboten on the bus. We've no car, no lift we could get or nothing. And Sandra's not able to stay on her own, so that's that" (Galloway 2015: 38 , emphasis in the original). This physical disconnection between Dianne and Sandra symbolised through the latter's inability to access to public transport emphasises the estrangement between mother and daughter that results from Dianne's failure to accept Sandra's mobility impairment: "[m]others take it hard if there's anything wrong in their wee ones, no matter how big the wee ones get. Sandra's near twenty-five but in my head, she's ten. She'll always be ten" (Galloway 2015: 39). Dianne plays with the belief that all mothers must take care of their children regardless of their age, although, in fact, she blocked off her feelings for her daughter following the accident and is in fact incapable of considering her an adult.

Nonetheless, living with other women who are mentally more vulnerable gives Dianne the confidence she cannot achieve at home. She experiences a spatial resilience that changes the meaning of the hospital to that of a home, for instance, by the fact that she is allowed to use the electric appliances in the kitchen as if she were not a patient. This privileged status - obtained as a result of her seniority because she has been in the hospital for a long time-- together with her capacity to rethink the space, gives her the opportunity to perform a motherly role with the female inpatients:

Dianne couldn't leave the kettle alone.

Tea? She held out a striped mug, not waiting for an answer. It's spare, she said. I like two on the go. (Galloway 2015: 37-38) 
If public transport disconnects Dianne from Sandra, tea helps her with her hospital mates. It acts as a symbolic amniotic fluid and the rest of the women become her potential children. Her behaviour towards them is based on the social misunderstanding of mentally-ill people as childish regardless of their age. Dianne behaves as a mother who does not take into account her children's will because they are not able to manage their lives alone.

However, Alma behaves as a counterpoint to Dianne since she has problems with the concept of motherhood. This is the reason why, although she accepts a cup of tea in order not to hurt Dianne's feelings, she ends up pouring it into the toilet, symbolising the rebirth of her subversive personality in relation to Dianne, in a symbolic "breaking of waters" that disconnects them:

Halfway down the corridor, she realised the mug was still in her hand. Lukewarm, the teabag still inside. She slid sideways into the nurse's toilet and poured the lot into the bowl. Auburn water in the toilet bowl, wood-tint red. Dianne's insides must be that colour, she thought, flushing, watching the tea caught up in the vortex from the cistern. (Galloway 2015: 39)

What is more, the tea reminds Alma of her abortion. The mahogany colour of the liquid is symbolic of the blood she lost in this traumatic experience, while the tea bag she tries to get rid of represents the aborted foetus. Consequently, Alma counters Dianne's perspective on the meaning of tea: although it stands for a stressful medical intervention in Alma's case, Dianne makes use of it to provide the other women with a state of relaxation and a feeling of protection that resembles the way the amniotic fluid would protect the foetus.

For this reason, Alma imagines the opposition between Dianne's blood, full of life, and her own feelings of emptiness after her abortion. She experiences her corporality and sexuality through what Kirsten Simonsen describes as a "cultural battlefield", where normativity on female bodily experiences can be questioned (2000: 7). This metaphoric space is strengthened by the maternal instinct she also develops towards Michelle, a wealthy but childish suicidal patient, who is not taken care of by Alma in the strict sense. When Michelle disappears because she has once more tried to commit suicide and is later isolated by the doctors, the protagonist undertakes the mission of finding her, to the point of breaking the rules of the mental institution and entering forbidden spaces at night, such as the library, where she finds Rhonda and hypocritically tells her: "[y]ou are breaking all the rules" (Galloway 2015: 47). This is not an insignificant statement. Rhonda is also suffering from post-abortion depression, in fact she has terminated seven pregnancies, so Alma identifies with her story and sees in her a reflection of her own grief. The fact that they break the rules not only refers to their behaviour inside the hospital; it can also be extrapolated to how women who do not accomplish their reproductive duty are socially condemned.

Additionally, although Alma is considered mentally impaired, she actually adopts a political and subversive attitude, especially against her boyfriend, Gerry, who does not understand why she has decided to be admitted voluntarily to the hospital. Alma will reconsider, for this purpose, the psychiatric hospital as a psychological space in which to develop her resilience, in line with her personal needs. Furthermore, she will need to reconfigure the moral structures that limit her life, so bearing in mind that she is voluntarily hospitalised, the space itself allows her to continue being the agent of her own decisions. Thus, the presence of the rest of the characters in the story invites her to re-establish personal relationships in a context where she feels she is an important member of the community and of the microcosm she inhabits. The short story substantially revises a resilient process that Janice Galloway had already referred to in The Trick Is to Keep Breathing. Joy Stone does not free herself until she uses her body as a political tool. Her anorexia, and therefore her disembodiment, allows her to reject her previous identity and to distance herself from conservative normativity (Russell 1996: 31). This reappropriation of her own body, together with the creation of new bonds of friendship with her hospital mates, will help her to articulate an alternative identity within a context regulated by very strict codes of conduct.

Doreen Massey (1994) views the political potential of space as both capable of delimiting identities and of confronting power structures. In this vein, we could also consider the psychiatric hospital as a safe space, a refuge (Curtis 2004), where Alma cohabits with other people who have undergone similar experiences. Interestingly, this understanding of the hospital as a secure place is necessary for her later social reintegration, in both physical and emotional terms. However, her post-abortion trauma and depression, two psychological conditions that are highly invisibilised in our society, limit her interaction, not only with the other women, but also, and particularly, with Gerry, who, exercising his authoritarianism, tries to convince her to leave the hospital:

Not wanting a baby was a joint decision, he said. It was the two of them on the same path. But this, he said, this. This was politics. He had tears in his eyes. Didn't she realise being in this place was a terrible mistake? They'd break her and make her ordinary. He wouldn't watch it happen. (Galloway 2015: 50-51, emphasis in the original) 
Although he admits his share of responsibility in the decision to abort, his objection is based on their affective bonds, which, as Linda McDowell (1999) contends, are crucial in the performance of gender roles that classify women as essentially emotional and men as rational. He claims that she will lose her uniqueness, but in fact we learn through the story that he considers her a mere tool to achieve his own selfish goals. Indeed, Alma becomes aware of this situation every time Gerry visits her: "[y]ou don't belong in this place. You're voluntary. Come home, Alma. I've got stuff. Stuff. (...) Stuff was not prescription meds for sad bastards, it was edgy and cool as shit and kissed with stardust" (Galloway 2015: 50; emphasis in the original). Alma thinks that her story resembles the story of the writer Trocchi's wife, as both men must deal with "cool stuff", as Gerry calls it, while their lovers suffer the consequences of being their partners. As such, her voluntary admission to the hospital can be read as a bolt from this damaging way of life. At this point, her decision becomes political, since her confinement in the hospital is in fact an attempt to find a refuge from her daily experiences.

Indeed, Alma starts to smile again when she discovers the power of sisterhood and the importance of having friends in the hospital. At first, her precarious mental situation leads her into continuous mourning because of the abortion: "[y]ou had to look at what you were doing, at who you were. This horrible, daily business of owning your own life. Answering to it. Knowing who you were" (Galloway 2015: 51). She thinks that the cause of her breakdown is personal when, in fact, all her problems evidence a social crisis involving the lack of an adequate care system and the constraints of femininity. Yet, the story also questions the indoctrination against and the censorship of alternative knowledges and conducts, as can be seen in Gerry's attitude:

Gerry didn't buy that. Psychiatric wards were for losers and dregs and depression didn't exist: it was just learned helplessness. He didn't believe in waiting or coming to terms: this was the belief of an oppressor that would not only benefit if she gave in. Gerry believed in junk. The things [sic] was, he needed her to believe it too. (Galloway 2015: 50)

Gerry represents a biased mentality that does not accept the social participation of people with psychological issues. However, his prejudice against legal medication clashes head-on with Alma's insinuation that, like Trocchi-who is represented in the story as a misogynist and a drug addict - Gerry is more open-minded towards synthetic drugs, which he also calls "cool stuff". There is a hierarchy based on discriminatory parameters, one that exists even among those citizens who are already excluded from the public realm. In this context, Alma is completely different for several reasons: being a woman, not fulfilling her reproductive role, being sick, and also for being hospitalised.

\section{Conclusions}

This comparative analysis of Galloway's novel The Trick Is to Keep Breathing and her short story "and drugs and rock and roll" shows how the author's narrative style has evolved from the late 1980s to the present day. In this dialogue between the two texts, women adopt their bodies as political weapons, but while Joy Stone only becomes aware of her potential at the end of the novel, Alma presents herself as a contemporary woman whose decisions, conditioned mainly by her personal needs and not by social expectations, will lead her to rediscover herself. The two texts are complementary in their exploration of female resilience within a medical institution from the perspective of a specific female archetype: traumatised women who partially recover after a stay in a psychiatric hospital. Their new forms of socialisation represent a turning point in their attempts to construct a new identity. They provide the psychiatric institution with new meanings by creating a microcosm in which ex-centric subjects become acceptable individuals to the rest of society. Although the psychiatric hospital limits the patients' life experiences by imposing schedules and specific norms of conduct, it also facilitates the development of forms of resilience that allow them to take control of their existence. This reconfiguration of their identities does not, though, imply escaping from social hierarchies, which are embedded in a culture that has configured gender mostly through corporality and affectivity. Nonetheless, it is precisely through these two constituents that the female characters in The Trick Is to Keep Breathing and in "and drugs and rock and roll" demonstrate their new attitudes and undergo their personal experiences in different ways. Although they are locked in the mental institution, and therefore they must follow specific norms of conviviality, these women rethink the space and find fractures through which they can establish a small community based on sisterhood and on the importance of achieving wellbeing regardless of their distinctive peculiarities. Galloway in this way shows women's ability to experience life in different, unexpected ways by tackling women's issues politically in order to create a fairer community, even within the most oppressive of environments. 


\section{References}

Ahmed, Sara and Jackie Stacy (2001). Thinking through the Skin. New York: Routledge.

Anderson, Carol (1993). Listening to the Women Talk. In Wallace, Gavin and Randall Stevenson, eds., 170-186.

Bell, Ian A. (1996). Imagine Living There: Form and Ideology in Contemporary Scottish Fiction. In Hagemann, Susanne, ed., 217-233.

Bentham, Jeremy (1995). The Panopticon Writings. London and New York: Verso.

Burgess, Moira (1998). Imagine a City: Glasgow in Fiction. Argyll: Argyll Publishing.

Buzzanell, Patrice (2010). Resilience: Talking, Resisting and Imagining New Normalcies into Being. Journal of Communication 60.1: 1-14.

Crampton, Jeremy W. and Elden Stuart, eds. (2007), Space, Knowledge and Power. Foucault and Geography. Burlington: Ashgate.

Curtis, Sarah (2004). Health and Inequality: Geographical Perspectives. London, Thousand Oaks and New Delhi: SAGE.

Curtis, Sarah (2016). Space, Place and Mental Health. New York: Routledge.

Delgado Delgado, Javier (2000). A Good Girl Is Hard to Find: The Politics of Janice Galloway's The Trick Is to Keep Breathing. EPOS 26: 315-331.

Evans, Brad and Julian Reid (2014). Resilient Life: The Art of Living Dangerously. Cambridge: Polity Press.

Foucault, Michel (2007a). The Incorporation of the Hospital into Modern Technology. In Crampton, Jeremy W. and Elden Stuart, eds., 141-151.

Foucault, Michel (2007b). Questions on Geography. In Crampton, Jeremy W. and Elden Stuart, eds., 173-182.

Galloway, Janice (1989). The Trick Is to Keep Breathing. London: Vintage.

Galloway, Janice (1997). Where You Find it. London: Vintage.

Galloway, Janice (2015). Jellyfish. Glasgow: Freight Books.

Hagemann, Susanne (1996). Studies in Scottish Fiction: 1945 to the Present. Frankfurt am Main: Peter Lang.

Hock Soon Ng, Andrew (2012). Coping with Reality: The Solace of Objects and Language in Janice Galloway's The Trick Is to Keep Breathing. Critique 53: 238-250.

Howson, Alexandra (2013). The Body in Society. Cambridge: Polity Press.

Jones, Carol (2009). Disappearing Men. Gender Disorientation in Scottish Fiction 1979-1999. Amsterdan and New York: Rodopi.

Malcolm, Cheryl Alexander and David Malcolm, eds. (2008), The British and Irish Short Story. New Jersey: WileyBlackwell.

Massey, Doreen (1994). Space, Place, and Gender. Minneapolis: University of Minnesota Press.

McDowell, Linda (1999). Gender, Identity and Place. Understanding Feminist Geographies. Oxford: Polity Press.

McGlynn, Mary (2008). 'I Didn't Need to Eat': Janice Galloway's Anorexic Text and the National Body. Critique 49.2: 221-236.

Meyer, Michael (2008). Feminist Voices: Women's Short Fiction after 1945. In Malcolm, Cheryl Alexander and David Malcolm, eds., 342-355.

Rodríguez González, Carla (2006). Los significados del cuerpo en The Trick Is to Keep Breathing, de Janice Galloway. Revista Canaria de Estudios Ingleses 53: 137-147.

Russell, Elizabeth (1996). Writing Abjection: Janice Galloway's The Trick Is to Keep on Breathing. Dedalus: Feminae: Figuras de Identidade 6: 29-36.

Sacido Romero, Jorge (2019). 'Being Then Nothing': Physicality, Abjection and Creation in Janice Galloway's Short Fiction. International Journal of English Studies 19.1: 133-150.

Sassen, Saskia (2000). Cities in a World Economy. Thousand Oaks, London and New Delhi: Pine Forge Press.

Schoene, Berthold (2007). The Edinburgh Companion to Contemporary Scottish Literature. Edinburgh: Edinburgh University Press.

Simonsen, Kirsten (2000). Editorial: The Body as Battlefield. Transactions of the Institute of British Geographers, New Series 25.1: 7-9.

Wallace, Gavin and Randall Stevenson, eds. (1993). The Scottish Novel Since the Seventies. Edinburgh: Edinburgh University Press.

Worell, Judith (2000). Feminism in Psychology: Revolution or Evolution? The ANNALS of the American Academy of Political and Social Science 571: 183-196. 